\title{
Synthesis and Photoluminescence of Polyketanils with Aliphatic Chains
}

\author{
Danuta $\mathrm{S}_{c} \mathrm{~K},{ }^{\dagger}$ Agnieszka Iwan, and Henryk JANECZEK \\ Centre of Polymer Chemistry, Polish Academy of Sciences, 34, M. Curie-Sklodowska Str., 41-819 Zabrze, Poland
}

(Received August 5, 2002; Accepted October 23, 2002)

\begin{abstract}
Novel polyketanils were synthesized via the polycondensation of diketones with two aliphatic diamines. The polyketanils were prepared in a one-step polycondensation in the presence of 1, 4-diazobicyclo[2, 2, 2]octane (DABCO) or DABCO and titanium tetrachloride. Thermal and luminescence properties were investigated. Polymers properties have been correlated with the length of aliphatic segments.
\end{abstract}

KEY WORDS Polyketanils / Ketimine / Thermostable Polymers / Fluorescence Properties /

Several research teams made studies polymers with $-\mathrm{C}=\mathrm{N}-$ groups in the main chain, i.e., polyazomethines and polyketanils. In contrary to polyazomethines, having hydrogen atom at imine carbon, polyketanils with aliphatic or aromatic substituents at imine carbon have not been widely studied. Previously, a few papers were published concerning synthesis and thermal properties of some polyketanils being the polycondensation products of diketones and diamines. ${ }^{1-8}$ However an increasing interest in polyketanils has been observed last by because of their potential application in optoelectronics. ${ }^{9,10}$

The main aim of this work was synthesis a series of new polyketanils and investigations of their photoluminescence and thermal properties. For synthesis five diketones, i.e., $p$-dibenzoylbenzene, $p$-dibenzoyltoluene, $p$-dibenzoylxylene, $p$-disebacoylbenzene and $p$-disebacoyltoluene and two aliphatic diamines, i.e., 1,6-diaminohexane and 1,7-diaminoheptane were used.

In the literature the only $p$-dibenzoylbenzene was reported to be used for polymers synthesis. ${ }^{1-3}$

However, according to the authors' best knowledge there are no works concerning studies of photoluminescence properties of this group of compounds. Spectroscopic studies of polyketanils were carried out for undoped and doped polymers with 1,2-(di-2ethylhexyl) ester of 4-sulfophthalic acid (abbreviated as DEHEPSA).

\section{EXPERIMENTAL}

\section{Materials}

1,6-Diaminohexane (Merck), 1,7-diaminoheptane (Merck) were used as laboratory reagents without further purification.

${ }^{\dagger}$ To whom correspondence should be addressed.
Terephthaloyl chloride (Aldrich), sebacoyl chloride (Aldrich), aluminium chloride (Aldrich), were used without purification.

Solvents: Acetone, benzene, toluene and $m$-cresol were dried and distilled in the usual manner; dimethylacetamide DMA (Aldrich), $p$-xylene (Aldrich), methanol, hexane were used without purification.

The protonating agent (DEHEPSA) was a gift from Prof. A. Pron from CEA in Grenoble.

\section{Measurements}

Glass transition temperatures of polymers (sample weight about $20 \mathrm{mg}$, heating rate of $20^{\circ} \mathrm{C} \mathrm{min}^{-1}$ ) and melting points of diketones (sample weight about $5 \mathrm{mg}$ at a heating rate of $5{ }^{\circ} \mathrm{Cmin}^{-1}$ ) were determined on a TA DSC 2010 apparatus using sealed aluminium pen under nitrogen atmosphere (flow rate about $30 \mathrm{~mL} \mathrm{~min}^{-1}$ ). Thermogravimetric (TG) analyses were performed on a Paulik-Erdey apparatus at a heating rate of $10^{\circ} \mathrm{C} \mathrm{min}^{-1}$ under nitrogen. For elemental analysis a 240C Perkin-Elmer analyser was used. Infrared spectra were acquired on a BIO-RAD FTS 40 A spectrometer. Measurements of the IR spectra were done using $\mathrm{KBr}$ disc. ${ }^{13} \mathrm{C}$ NMR spectra were recorded on a Varian Inova 300 Spectrometer using DMSO- $d_{6}$ as a solvent and TMS as an internal reference. UV-VIS spectra were recorded in DMA solution (conc. $10^{-5} \mathrm{~mol} \mathrm{~L}^{-1}$ ) using a Beckman Acta M I V. Fluorescence spectra were acquired on a spectrophotometer Fluorolog 3.12 Spex (USA). Gel permeation chromatography (GPC) experiments were carried out on a Spectra Physics 8800 in temperature $35^{\circ} \mathrm{C}$. A differential refractometer Shodex SE61 was used as detector. Tetrahydrofuran was used as the eluent and polystyrene-as standard.

\section{Synthesis of Diketones}

Synthesis of $p$-dibenzoylbenzene (Friedel-Crafts acylation of benzene with terephthaloyl chloride in the 
Table I. Properties of diketones

\begin{tabular}{|c|c|c|c|c|}
\hline \multirow{3}{*}{$\begin{array}{l}\text { Structure } \\
\text { (Code) }\end{array}$} & \multirow{3}{*}{$\begin{array}{l}\mathrm{mp}^{\mathrm{a}} \\
\left({ }^{\circ} \mathrm{C}\right)\end{array}$} & \multicolumn{2}{|c|}{$\begin{array}{l}\text { Elemental } \\
\text { Analysis }\end{array}$} & \multirow{3}{*}{$\begin{array}{l}\text { FT-IR (KBr) } \\
\quad\left(\mathrm{cm}^{-1}\right)\end{array}$} \\
\hline & & $\begin{array}{c}\text { Carbon } \\
(\%)\end{array}$ & $\begin{array}{c}\text { Hydrogen } \\
(\%)\end{array}$ & \\
\hline & & $\begin{array}{l}\text { Found } \\
\text { (Calcd) }\end{array}$ & $\begin{array}{l}\text { Found } \\
\text { (Calcd) }\end{array}$ & \\
\hline \multirow{3}{*}{$\begin{array}{l}\text { (DT) }\end{array}$} & 161 & $\begin{array}{c}83.56 \\
(83.89)\end{array}$ & $\begin{array}{c}4.86 \\
(4.93)\end{array}$ & $\begin{array}{l}3084(\mathrm{C}-\mathrm{H} \text { ar. stretch.), } 1657(\mathbf{C}=\mathbf{O}), 1595,1576,1447 \text { (phenyl ring } \\
\text { stretch.), 677, 708, 783, } 858(\mathrm{C}-\mathrm{H} \text { arom. out of plane deform.), 1070, } \\
1109,1158,1270 \text { (1.4-subst. and mono subst. phenyl ring } \mathrm{C}-\mathrm{H} \text { deform.) }\end{array}$ \\
\hline & 192 & $\begin{array}{c}84.39 \\
(84.05)\end{array}$ & $\begin{array}{c}5.92 \\
(5.77)\end{array}$ & $\begin{array}{l}3029(=\mathrm{C}-\mathrm{H} \text { stretch. }), 2950\left(\mathrm{CH}_{3}\right), \mathbf{1 6 5 1}(\mathbf{C}=\mathbf{O}), 1605,1448,1401 \\
\text { (phenyl ring stretch.), 691, 737, 822, } 860(\mathrm{C}-\mathrm{H} \text { arom. out of plane de- } \\
\text { form.), 925, 1035, 1155, } 1272(1.4 \text {-subst. phenyl ring } \mathrm{C}-\mathrm{H} \text { deform. })\end{array}$ \\
\hline & 119 & $\begin{array}{c}84.04 \\
(84.18)\end{array}$ & $\begin{array}{c}6.37 \\
(6.48)\end{array}$ & $\begin{array}{l}3025(=\mathrm{C}-\mathrm{H} \text { stretch. }), 2962\left(\mathrm{CH}_{3}\right), \mathbf{1 6 5 9}(\mathbf{C}=\mathbf{O}), 1569,1500,1451 \\
\text { (phenyl ring stretch.),695, 747, 826, } 843(\mathrm{C}-\mathrm{H} \text { arom. out of plane } \\
\text { deform.), 949, 1041, 1112,1157, } 1261 \text { (1.4-subst. phenyl ring } \mathrm{C}-\mathrm{H} \\
\text { deform.) }\end{array}$ \\
\hline (DA) & 95 & $\begin{array}{c}81.44 \\
(81.95)\end{array}$ & $\begin{array}{c}8.19 \\
(8.13)\end{array}$ & $\begin{array}{l}3037 \text { (C-H arom. strech.), 2925, 2910, } 2845 \text { (C-H aliph. stretch.), } 1682 \\
(\mathbf{C}=\mathbf{O}), 1605,1574,1450,1406 \text { (phenyl ring stretch.), } 1468(\mathrm{C}-\mathrm{H} \text { def } \\
\text { aliph.), 725, } 815 \text { (C-H arom. out of plane deform.), 979, 1069, 1107, } \\
1181,1212 \text { (mono subst. phenyl ring C-H aliph.), } 2859\left(-\mathrm{CH}_{3}\right)\end{array}$ \\
\hline (DAT) & 101 & $\begin{array}{c}82.83 \\
(82.24)\end{array}$ & $\begin{array}{c}8.79 \\
(8.63)\end{array}$ & $\begin{array}{l}3057 \text { (C-H arom. strech.), 2931, 2913, } 2850 \text { (C-H aliph. stretch.), } 1685 \\
(\mathbf{C}=\mathbf{O}), 1596,1576,1447 \text { (phenyl ring stretch.), } 1464 \text { (C-H def aliph.), } \\
\text { 689, } 736 \text { (C-H arom. out of plane deform.), 975, 1187, } 1226 \text { (mono } \\
\text { subst. phenyl ring C-H aliph.) }\end{array}$ \\
\hline
\end{tabular}

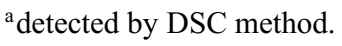

presence of aluminium chloride) was carried out as described in the literature. ${ }^{1-3}$ The new diketones were synthesised using the same method, i.e., Friedel-Crafts acylation of toluene or $p$-xylene with terephthaloyl or sebacoyl chloride. Recrystallization of the crude compounds was carried out from a mixture of acetonehexane $(1: 2 \mathrm{v} / \mathrm{v})$.

\section{Polymers Synthesis}

High temperature polycondensation was used for preparation of the polymers. A diketone $(1 \mathrm{mmol})$ and a diamine ( $1 \mathrm{mmol}$ ) were heated and stirred in $4 \mathrm{~mL}$ of $m$ cresol at $180^{\circ} \mathrm{C}$ for $48 \mathrm{~h}$ under nitrogen atmosphere in the presence of DABCO $(2 \mathrm{mmol})$ or $\mathrm{DABCO}+\mathrm{TiCl}_{4}$ $(2 \mathrm{mmol}+0.5 \mathrm{mmol})$. The polymer was precipitated into methanol. The product was collected by filtration, purified by Soxhlet extraction with methanol and dried at $150^{\circ} \mathrm{C}$ under vacuum for $24 \mathrm{~h}$.

\section{RESULTS AND DISCUSSION}

\section{Characterisation of New Diketones}

The structures of the diketones were confirmed by elemental analysis and spectroscopy methods (FT-IR, NMR,) and their characteristics are collected in Table I.

Absorption bands in the range of $1650 \mathrm{~cm}^{-1}$
$1685 \mathrm{~cm}^{-1}$ characteristic for carbonyl group in ketone were observed in the IR spectra. In the reaction of terephthaloyl chloride with toluene there are two possibilities of a substitution, i.e., para or ortho position. Analysis of over-tone region in FT-IR spectrum confirms the substitution at para position (absorption bands at $1935 \mathrm{~cm}^{-1}$, at $1817 \mathrm{~cm}^{-1}$, and $1700 \mathrm{~cm}^{-1}$ ).

In the ${ }^{13} \mathrm{C}$ NMR spectra a peak characteristic for carbon atom in carbonyl group was detected at $194 \mathrm{ppm}$ for diketones DB and DT. In the case of the diketone with methyl group at ortho position to carbonyl group (DK) the peak is shifted to $196.9 \mathrm{ppm}$. In the diketones DA and DAT with aliphatic chain between carbonyl groups, the peak is shifted to $199.2 \mathrm{ppm}$. Assignments of the remaining absorbance are shown in Table II.

\section{Characterisation of Polymers}

Structure of the polymers is presented in Figure 1 and some their properties are listed in Table III.

The polyketanils were soluble in $m$-cresol, DMF, DMA except the polymer DB7. In FT-IR spectra the absorption band in the range $1608-1612 \mathrm{~cm}^{-1}$, being characteristic for $-\mathrm{C}=\mathrm{N}-$ group along with the $\mathrm{ab}-$ sorption due to phenyl ring confirmed structure of the polyketanils. Thermal stability of the polyketanils was investigated by thermogravimetric analysis. These 
Table II. ${ }^{1} \mathrm{H}$ and ${ }^{13} \mathrm{C}$ NMR assignments

\begin{tabular}{|c|c|c|c|c|c|c|c|c|c|c|c|c|}
\hline \multirow{2}{*}{ Structure } & \multicolumn{12}{|c|}{${ }^{13} \mathrm{C}$ NMR (ppm) } \\
\hline & 1 & 2 & 3 & 4 & 5 & 6 & 7 & 8 & 9 & 10 & 11 & $\mathrm{CH}_{3}$ \\
\hline & 132.52 & 128.21 & 128.93 & 136.33 & 194.84 & 139.87 & 129.17 & & & & & \\
\hline${ }^{1} \mathrm{H}$ NMR (ppm) & $\begin{array}{c}\text { 2Har. } \\
7.71(\mathrm{~m})\end{array}$ & $\begin{array}{c}\text { 4Har. } \\
7.58(\mathrm{~m})\end{array}$ & $\begin{array}{c}\text { 4Har. } \\
7.81(\mathrm{~m})\end{array}$ & - & - & - & $\begin{array}{l}\text { 4Har. } \\
7.87(\mathrm{~s})\end{array}$ & - & - & - & - & - \\
\hline & 143.12 & 128.79 & 128.75 & 133.69 & 194.46 & 140.05 & 129.39 & & & & & 20.69 \\
\hline${ }^{1} \mathrm{H}$ NMR (ppm) & - & $\begin{array}{l}\text { 4CHar. } \\
7.38 \text { (d) }\end{array}$ & $\begin{array}{l}\text { 4CHar. } \\
7.74 \text { (d) }\end{array}$ & - & - & - & $\begin{array}{l}\text { 4Har. } \\
7.84(\mathrm{~s})\end{array}$ & - & - & - & - & $\begin{array}{c}2 \mathrm{CH}_{3} \\
2.41(\mathrm{~s})\end{array}$ \\
\hline & 130.91 & 130.53 & 132.57 & 137.42 & 196.93 & 140.36 & 129.23 & 128.23 & 134.35 & & & $\begin{array}{l}19.88 \\
18.53\end{array}$ \\
\hline${ }^{1} \mathrm{H}$ NMR (ppm) & $\begin{array}{c}\text { 2Har. } \\
7.26(\mathrm{~m})\end{array}$ & $\begin{array}{c}\text { 2Har. } \\
7.14(\mathrm{~m})\end{array}$ & - & - & - & - & $\begin{array}{l}\text { 4Har. } \\
7.82(\mathrm{~s})\end{array}$ & $\begin{array}{c}\text { 2Har. } \\
7.29(\mathrm{~m})\end{array}$ & - & - & - & $\begin{array}{c}2 \mathrm{CH}_{3} \\
2.19(\mathrm{~s}) \\
2.28(\mathrm{~s})\end{array}$ \\
\hline & 132.32 & 127.33 & 128.15 & 136.68 & 199.66 & & & 37.54 & 23.50 & 28.16 & 28.24 & \\
\hline${ }^{1} \mathrm{H}$ NMR (ppm) & $\begin{array}{c}\text { 2Har. } \\
7.61(\mathrm{~m})\end{array}$ & $\begin{array}{c}\text { 4Har. } \\
7.50(\mathrm{~m})\end{array}$ & $\begin{array}{c}\text { 4Har. } \\
7.94(\mathrm{~m})\end{array}$ & - & - & - & - & $\begin{array}{c}2 \mathrm{CH}_{2} \\
2.99(\mathrm{t})\end{array}$ & $\begin{array}{c}2 \mathrm{CH}_{2} \\
1.59(\mathrm{~m})\end{array}$ & $\begin{array}{c}2 \mathrm{CH}_{2} \\
1.29(\mathrm{~m})\end{array}$ & $\begin{array}{c}2 \mathrm{CH}_{2} \\
1.29(\mathrm{~m})\end{array}$ & - \\
\hline & 142.70 & 128.73 & 127.48 & 134.22 & 199.17 & & & 37.43 & 23.62 & 28.19 & 28.25 & 20.57 \\
\hline${ }^{1} \mathrm{H}$ NMR (ppm) & - & $\begin{array}{l}\text { 4CHar. } \\
7.30 \text { (d) }\end{array}$ & $\begin{array}{l}\text { 4CHar. } \\
7.84 \text { (d) }\end{array}$ & - & - & - & - & $\begin{array}{c}2 \mathrm{CH}_{2} \\
2.94(\mathrm{t})\end{array}$ & $\begin{array}{c}2 \mathrm{CH}_{2} \\
1.56(\mathrm{~m})\end{array}$ & $\begin{array}{c}2 \mathrm{CH}_{2} \\
1.28(\mathrm{~m})\end{array}$ & $\begin{array}{c}2 \mathrm{CH}_{2} \\
1.28(\mathrm{~m})\end{array}$ & $\begin{array}{c}2 \mathrm{CH}_{3} \\
2.36(\mathrm{~s})\end{array}$ \\
\hline
\end{tabular}
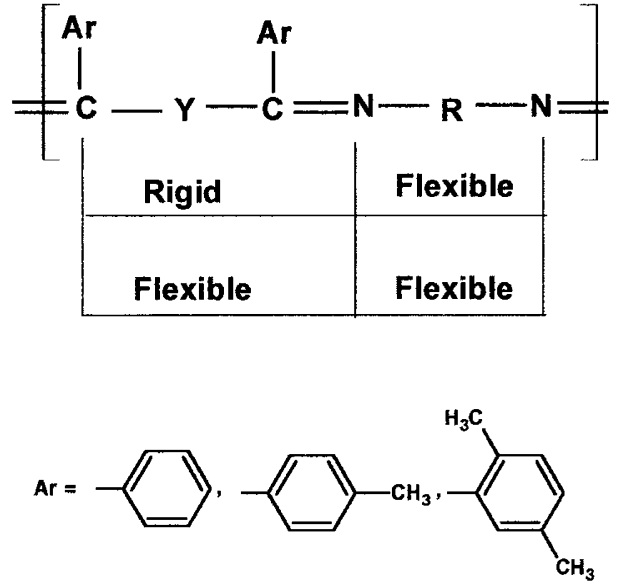

$\mathrm{R}=-\left(\mathrm{CH}_{2}\right)_{6}^{-},-\left(\mathrm{CH}_{2}\right)_{7}$

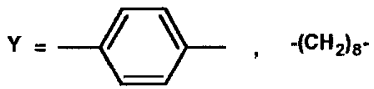

Figure 1. Structure of polymers.

polymers lost $10 \%$ weight at temperatures in the range of $330-420{ }^{\circ} \mathrm{C}$ in nitrogen. The residue at $1000^{\circ} \mathrm{C}$ is between $56-63 \%$. Glass transition temperatures de- pend on the polymers structure and were observed in the range of $134-305^{\circ} \mathrm{C}$. It was not possible to detect glass transition temperature for the polymer DB7. Generally, polymers obtained from 1,6-diaminohexane have the lower glass transition temperatures than the polymers from 1,7-diaminoheptane and the same diketones. This result is unexpected because in the many polymers those with odd number of $\left(\mathrm{CH}_{2}\right)$ groups in the chain exhibit lower $T_{\mathrm{g}}$ than with even ones and a longer aliphatic chain usually lowers temperature of the glass transition. Molecular weights of the polymers from these two diamines and proper diketones differ very little and it cannot be a reason of the various $T_{\mathrm{g}}$ 's. Of course, the glass transition temperatures depend on molecular weights to some extend but the influence of the polymer chemical structure should not differ very much in the case of high or low molecular weight of the polymers. It seems that the different conformations of the polymers chains might be responsible for the observed phenomenon. Polyketanils prepared in the presence of DABCO (Table III) have not high molecular weight (detected by GPC). When a mix- 
Table III. Some properties of the new polyketanils (synthesized in the presence of DABCO)

\begin{tabular}{|c|c|c|c|c|c|}
\hline \multirow[b]{2}{*}{$\begin{array}{l}\text { Structure } \\
\text { (Code) }\end{array}$} & \multirow[b]{2}{*}{$\begin{array}{c}T_{\mathrm{g}} \\
\left({ }^{\circ} \mathrm{C}\right)\end{array}$} & \multicolumn{2}{|c|}{ TG in argon } & \multirow[b]{2}{*}{$\begin{array}{l}\text { FT-IR (KBr) } \\
\quad\left(\mathrm{cm}^{-1}\right)\end{array}$} & \multirow[b]{2}{*}{$\begin{array}{c}M_{\mathrm{n}} \\
(\mathrm{GPC})\end{array}$} \\
\hline & & $\begin{array}{c}10 \% \\
\text { weight } \\
\text { loss }\left({ }^{\circ} \mathrm{C}\right)\end{array}$ & $\begin{array}{c}\text { Residue at } \\
1000^{\circ} \mathrm{C} \\
(\%)\end{array}$ & & \\
\hline & 193 & 420 & 62 & $\begin{array}{l}\text { 3510, } 3386 \text { (N-H stretch in amine end groups), } 3029 \text { (C-H arom. } \\
\text { stretch.), 2922, } 2861 \text { (C-H aliph. stretch.), } 1611 \text { (C=N), 1586, 1495, } \\
1416 \text { (phenyl ring stretch.), } 1451 \text { (C-H aliph. deform.), 701, 781, } 809 \\
\text { (C-H arom out of plane deform.), 1034, 1160, } 1247 \text { (1.4 subst. and mono } \\
\text { subst. phenyl ring C-H deform.) }\end{array}$ & 2400 \\
\hline r & ND & 420 & 63 & $\begin{array}{l}3028 \text { (C-H arom. stretch.), 2922, } 2861(\mathrm{C}-\mathrm{H} \text { aliph stretch. }), \mathbf{1 6 1 1}(\mathbf{C}=\mathbf{N}) \text {, } \\
\text { 1588, } 1492,1416 \text { (phenyl ring stretch.), } 1452(\mathrm{C}-\mathrm{H} \text { aliph. deform. }), 702, \\
781,811 \text { (C-H arom. out of plane deform.), 1035, 1159, } 1246(1.4 \text { and } \\
\text { mono subst. phenyl ring C-H deform.) }\end{array}$ & - \\
\hline (D & 162 & 370 & 62 & $\begin{array}{l}3510,3386(\mathrm{~N}-\mathrm{H} \text { stretch. in amine end group), } 3029(\mathrm{C}-\mathrm{H} \text { arom. } \\
\text { stretch. }), 2922,2861(\mathrm{C}-\mathrm{H} \text { aliph stretch. }), 2950\left(-\mathrm{CH}_{3}\right), \mathbf{1 6 0 8}(\mathbf{C}=\mathbf{N}) \text {, } \\
\text { 1586, 1497, } 1416 \text { (phenyl ring stretch.), } 1452(\mathrm{C}-\mathrm{H} \text { aliph. deform. }), 691, \\
737,809,862(\mathrm{C}-\mathrm{H} \text { arom. out of plane deform. }), 952,1034,1160,1248 \\
\text { (1.4 subst. phenyl ring } \mathrm{C}-\mathrm{H} \text { deform.) }\end{array}$ & 2400 \\
\hline & 304 & 370 & 63 & $\begin{array}{l}3510,3344 \text { (N-H stretch. in amine end group), } 3029(\mathrm{C}-\mathrm{H} \text { arom. } \\
\text { stretch.), } 2921,2859\left(\mathrm{C}-\mathrm{H} \text { aliph. stretch.), } 2950\left(-\mathrm{CH}_{3}\right), \mathbf{1 6 0 9}(\mathbf{C}=\mathbf{N}) \text {, }\right. \\
\text { 1584, 1496, } 1417 \text { (phenyl ring stretch.) } 1454(\mathrm{C}-\mathrm{H} \text { aliph. deform.), } 691 \text {, } \\
737,810,863(\mathrm{C}-\mathrm{H} \text { arom. out of plane deform.), 953, 1034, 1160, } 1247 \\
\text { (1.4 subst. phenyl ring C-H deform.) }\end{array}$ & 2500 \\
\hline & 250 & 370 & 54 & $\begin{array}{l}\text { 3510, } 3381 \text { (N-H stretch. in amine end group), } 3028(\mathrm{C}-\mathrm{H} \text { arom. } \\
\text { stretch.), 2922, } 2861\left(\mathrm{C}-\mathrm{H} \text { aliph. stretch.), } 2962\left(-\mathrm{CH}_{3}\right), \mathbf{1 6 1 1}(\mathbf{C}=\mathbf{N}) \text {, }\right. \\
\text { 1586, 1497, } 1416 \text { (phenyl ring stretch.) } 1452(\mathrm{C}-\mathrm{H} \text { aliph. deform.), 689, } \\
737,808,862(\mathrm{C}-\mathrm{H} \text { arom. out of plane deform.), 951, 1033, 1158, 1260, } \\
1294 \text { (1.4 subst. phenyl ring C-H deform.) }\end{array}$ & 1600 \\
\hline & 305 & 355 & 56 & $\begin{array}{l}3511,3382(\mathrm{~N}-\mathrm{H} \text { stretch. in amine end group), } 3029(\mathrm{C}-\mathrm{H} \text { arom. } \\
\text { stretch.), } 2923,2860\left(\mathrm{C}-\mathrm{H} \text { aliph. stretch.), } 2962\left(-\mathrm{CH}_{3}\right), \mathbf{1 6 1 1}(\mathbf{C}=\mathbf{N}) \text {, }\right. \\
\text { 1586, 1497, } 1416 \text { (phenyl ring stretch.) } 1454(\mathrm{C}-\mathrm{H} \text { aliph. deform.), 689, } \\
737,811,863(\mathrm{C}-\mathrm{H} \text { arom. out of plane deform.), 953, 1034, 1160, 1247, } \\
1295 \text { (1.4 subst. phenyl ring C-H deform.) }\end{array}$ & 2700 \\
\hline & 134 & 330 & 48 & $\begin{array}{l}\text { 3509, } 3371 \text { (N-H stretch. in amine end group), } 3027 \text { (C-H arom. } \\
\text { stretch.), 2924, } 2858(\mathrm{C}-\mathrm{H} \text { aliph. stretch.), } \mathbf{1 6 1 2}(\mathbf{C}=\mathbf{N}), 1583,1498, \\
1416 \text { (phenyl ring stretch.) } 1449(\mathrm{C}-\mathrm{H} \text { aliph. deform.), 699, 736, 809, } \\
862 \text { (C-H arom. out of plane deform.), 949, 1158, } 1247 \text { (mono subst. } \\
\text { phenyl ring C-H deform.) }\end{array}$ & 1600 \\
\hline & 187 & 335 & 53 & $\begin{array}{l}\text { 3509, } 3377 \text { (N-H stretch. in amine end group), } 3028 \text { (C-H arom. } \\
\text { stretch.), 2925, } 2858 \text { (C-H aliph. stretch.), } 1612(\mathbf{C}=\mathbf{N}), 1584,1498, \\
1421 \text { (phenyl ring stretch.) } 1450(\mathrm{C}-\mathrm{H} \text { aliph. deform.), 699, 736, 809, } \\
862 \text { (C-H arom. out of plane deform.), 948, 1159, } 1248 \text { (mono subst. } \\
\text { phenyl ring C-H deform.) }\end{array}$ & 1900 \\
\hline (D) & 155 & 350 & 50 & $\begin{array}{l}3509,3375 \text { (N-H stretch. in amine end group), } 3026(\mathrm{C}-\mathrm{H} \text { arom. } \\
\text { stretch.), } 2923\left(\mathrm{C}-\mathrm{H} \text { aliph. stretch.), } 2858\left(-\mathrm{CH}_{3}\right), \mathbf{1 6 0 8}(\mathbf{C}=\mathbf{N}), 1585 \text {, }\right. \\
\text { 1499, } 1422 \text { (phenyl ring stretch.) } 1452(\mathrm{C}-\mathrm{H} \text { aliph. deform. }), 733,810, \\
862 \text { (C-H arom. out of plane deform.), 949, 1181, } 1248 \text { (mono subst. } \\
\text { phenyl ring C-H deform.) }\end{array}$ & 1500 \\
\hline$(\mathrm{DAT} 7)$ & 222 & 355 & 49 & $\begin{array}{l}\text { 3509, } 3349 \text { (N-H stretch. in amine end group), } 3028(\mathrm{C}-\mathrm{H} \text { arom. } \\
\text { stretch.), } 2924\left(\mathrm{C}-\mathrm{H} \text { aliph. stretch.), } 2859\left(-\mathrm{CH}_{3}\right), \mathbf{1 6 0 8}(\mathbf{C}=\mathrm{N}), 1585,\right. \\
\text { 1497, } 1419 \text { (phenyl ring stretch.) } 1454(\mathrm{C}-\mathrm{H} \text { aliph. deform. }), 737,810, \\
863 \text { (C-H arom. out of plane deform.), 952, 1181, } 1248 \text { (mono subst. } \\
\text { phenyl ring C-H deform.) }\end{array}$ & 1500 \\
\hline
\end{tabular}


Table IV. Influence of the catalysts on $M_{\mathrm{n}}$ and $T_{\mathrm{g}}$ of the polyketanils

\begin{tabular}{|c|c|c|c|c|}
\hline \multirow{2}{*}{ Code } & \multicolumn{2}{|c|}{ Dabco } & \multicolumn{2}{|c|}{ Dabco: $\mathrm{TiCl}_{4}(2: 0.5)$} \\
\hline & $\begin{array}{c}\overline{T_{\mathrm{g}}} \\
\left({ }^{\circ} \mathrm{C}\right)\end{array}$ & $\begin{array}{c}M_{\mathrm{n}} \\
(\mathrm{GPC})\end{array}$ & $\begin{array}{c}T_{\mathrm{g}} \\
\left({ }^{\circ} \mathrm{C}\right)\end{array}$ & $\begin{array}{c}M_{\mathrm{n}} \\
(\mathrm{GPC})\end{array}$ \\
\hline DK6 & 250 & $1.6 \times 10^{3}$ & ND & $2 \times 10^{6}$ \\
\hline DK7 & 305 & $2.7 \times 10^{3}$ & 349 & $1.7 \times 10^{5}$ \\
\hline DA6 & 134 & $1.6 \times 10^{3}$ & ND & $7.5 \times 10^{5}$ \\
\hline DA7 & 187 & $1.9 \times 10^{3}$ & 302 & $1.2 \times 10^{5}$ \\
\hline
\end{tabular}

Table V. Maximum emission band wavelength of the polyketanils before and after doping

\begin{tabular}{ccc}
\hline \multirow{2}{*}{$\begin{array}{c}\text { Polymer } \\
\text { (code as in Table II) }\end{array}$} & \multicolumn{2}{c}{$\begin{array}{c}\text { Photoluminescence } \\
(\mathrm{nm})\end{array}$} \\
\cline { 2 - 3 } & Undoped & Doped with DEHEPSA \\
\hline DB6 & 474 & 519 \\
DT6 & 501 & 504 \\
DT7 & $\mathbf{5 2 5}$ & $\mathbf{5 0 1}$ \\
DK6 & 486 & 494 \\
DK7 & $\mathbf{5 3 6}$ & $\mathbf{5 1 6}$ \\
DA6 & 473 & 475 \\
DA7 & $\mathbf{4 9 4}$ & $\mathbf{4 8 8}$ \\
DAT6 & 484 & 485 \\
DAT7 & $\mathbf{5 0 7}$ & $\mathbf{4 7 8}$ \\
\hline
\end{tabular}

ture of $\mathrm{DABCO}+\mathrm{TiCl}_{4}$ was used as catalyst polymers with higher molecular weight and higher glass transition temperature were obtained. Table IV shows the influence of the catalysts on $T_{\mathrm{g}}$ and $M_{\mathrm{n}}$ for selected polymers.

But the last catalytic system exhibits inconvenience because of the difficulty of titanium derivative traces removing.

In UV VIS spectra of the polyketanils in DMA solution strong absorption band in the range of $270-280 \mathrm{~nm}$ and weak (broad and with low intensities) at 345$370 \mathrm{~nm}$ were detected. For polyketanils (as in Table III) photoluminescence was detected. Measurements were done in DMA solution (conc. $10^{-4} \mathrm{~mol} \mathrm{~L}^{-1}$ ) for undoped and doped polymers with DEHEPSA (ratio: $2 \mathrm{~mol}$ DEHEPSA for $1 \mathrm{~mol}$ of polymer). Emission spectra of the polyketanils have very similar shape. In Table $\mathrm{V}$ the values of the maximum emission band wavelength are collected.

Undoped polyketanils obtained from 1,7diaminoheptane exhibit maximum emission band in the range of $494-525 \mathrm{~nm}$. The values for the polymers prepared from 1,6-diaminohexane there are between $473-501 \mathrm{~nm}$. The emission bands of the polyketanils synthesized from diamine having odd number of $\left(\mathrm{CH}_{2}\right)$ groups and the all diketones are batochromic shifted in comparison to the polymers from the diamine with even $\left(\mathrm{CH}_{2}\right)$ groups.

Doping of the polyketanils with DEHEPSA influ-

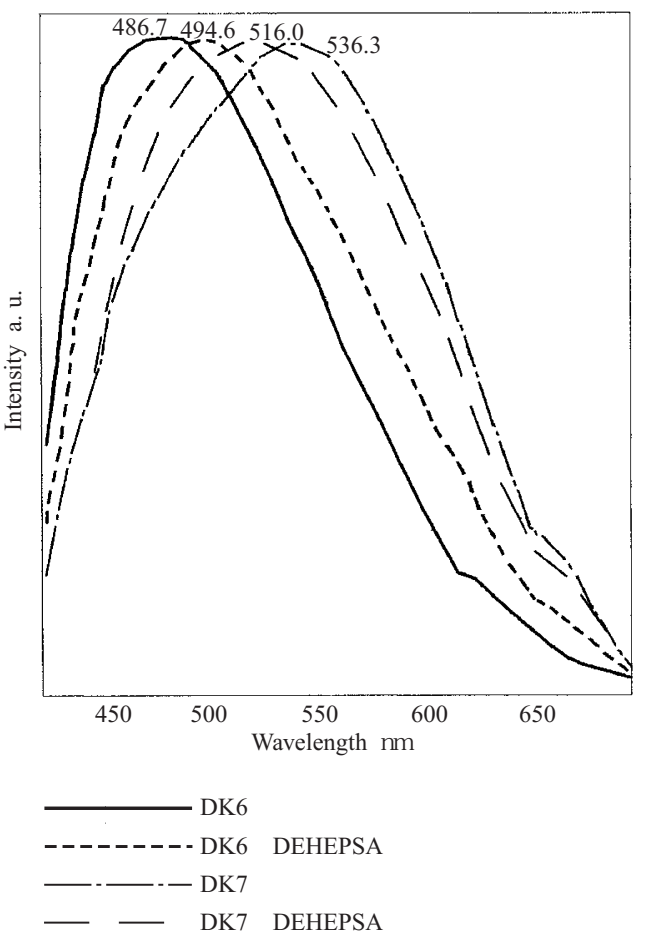

Figure 2. Emission spectra of the polymer DK6 and DK7 before and after doping.

ences on the emission wavelength in different way.

The polyketanils synthesized from 1,6diaminohexane and all the diketones after doping exhibited a little batochromic shift in comparison to the undoped ones. The bigger shift was observed only for the polymer DB6. On the other hand the polymers from 1,7-diaminoheptane and all the diketones after doping with DEHEPSA showed hipsochromic shift of the emission band in comparison with undoped ones.

Figure 2 shows the emission spectra of DK6 and DK7 before and after doping, as an example.

Intra and inter molecular interactions can influence on photoluminescence. Possible reason of the different behaviour of the polyketanils with aliphatic chains after protonation with bulky DEHEPSA molecule can be the different configurational intereactions between the polymer chains with odd and even $\left(\mathrm{CH}_{2}\right)$ groups.

To the authors' best knowledge no works concerning study of photoluminescence of polymers with imine groups (polyazomethines, polyketanils) in the main chains after protonation have been published. Therefore additional investigations have to be done to solve problem and the work is in progress.

\section{CONCLUSION}

A series of new polyketanils was synthesised using different diketones and two aliphatic diamines. The 
polyketanils exhibit high thermal stability and their glass transition temperatures depend on the structure of monomers. It was unexpected that the glass transition temperatures of the polyketanils synthesized from 1, 7diaminoheptane (in the presence DABCO as catalyst), i.e., having odd number of $\left(\mathrm{CH}_{2}\right)$ groups are higher than the $T_{\mathrm{g}}$ of the polymers from 1,6-diaminohexane. The structure of the diamine influences also on the photoluminescence emission band. Undoped polyketanils obtained from 1,7-diaminoheptane exhibited batochromic shift of the emission band in comparison with the polymers obtained from 1,6-diaminohexane. Doping of the polyketanils with 1,2-(di-2-ethylhexyl)ester of 4sulfophthalic acid (DEHEPSA) caused very little batochromic shift of the emission band in the case of polyketanils from 1, 6-diaminohexane while for the series of polymers from 1,7-diaminoheptane - a hipsochromic shift was observed in comparison with the undoped polymers.

Acknowledgments. The authors are grateful to Dr. Z. Mazurak for detected of PL spectra and Dr. J. Kasperczyk for NMR measurements and discussion.

\section{REFERENCES}

1. A. A. Volpe, L. G. Kaufman, R. G. and Dondero, in "Polymers in Space research", Ch. L. Segal, M. Shen, and F. N. Kelley, Ed., Marcel Dekker, Inc., New York, N.Y., 1970.

2. A. A. Volpe, L. G. Kaufman, and R. G. Dondero, J. Macromol. Sci. Chem., A3, 1087 (1969).

3. L. G. Kaufman, P. T. Funke, and A. A. Volpe, Macromolecules, 3, 358 (1970).

4. D. Sęk, Polym. J., 13, 13 (1981).

5. S. Banerjee, C. Saxena, P. K. Gutch, and D. C. Gupta, Eur. Polym. J., 32, 661 (1996).

6. C. Yeakel, K. Gower, and R. S. Mani, Macromol. Chem., 194, 2779 (1993).

7. M. S. Patel and S. R. Patel, J. Polym. Sci., Polym. Chem. Ed., 20, 1985 (1982)

8. M. Higuchi, A. Kimoto, H. Kanazawa, and K. Yamamoto, Org. Lett., 1, 1881 (1999).

9. M. Higuchi, A. Kimoto, S. Shiki, and K. Yamamoto, J. Org. Chem., 65, 5680 (2000).

10. S. Shiki, M. Higuchi, and K. Yamamoto, Abstracts of Polycondensation 2000 Symposium, Tokyo, September, 2000. 